19 Revue d'histoire du XIXe siècle

Société d'histoire de la révolution de 1848 et des

révolutions du XIXe siècle

17| 1998

Les foules au XIXe siècle

\title{
Introduction. Les foules au XIXe siècle
}

Jean-Yves Mollier

URL: http://journals.openedition.org/rh19/137

DOI: $10.4000 /$ rh 19.137

ISSN: $1777-5329$

Publisher

La Société de 1848

Printed version

Date of publication: 1 December 1998

ISSN: 1265-1354

Electronic reference

Jean-Yves Mollier, «Introduction. Les foules au XIXe siècle », Revue d'histoire du XIXe siècle [Online],

17 | 1998, Online since 10 September 2008, connection on 20 April 2019. URL : http:// journals.openedition.org/rh19/137; DOI : 10.4000/rh19.137

This text was automatically generated on 20 April 2019

Tous droits réservés 


\section{Introduction. Les foules au XIXe siècle}

Jean-Yves Mollier

ABSTRACTS

No abstract available by now

Pas de résumé disponible actuellement

INDEX

Mots-clés: Foules 